\title{
Technology Levels in Cassava Cultivation Alter Phytosociology of Weeds
}

Isabel Schlegel Werle

Crop, Soil, and Environmental Sciences, University of Arkansas, Fayetteville, 1366 West Altheimer Drive, AR 72704

\author{
Alencar Junior Zanon \\ Department of Plant Sciences, Federal University of Santa Maria \\ (UFSM), Santa Maria, 1000 Roraima Avenue, 97105-900, Brazil
}

Nereu Augusto Streck

Department of Plant Sciences, Federal University of Santa Maria (UFSM), Santa Maria, 1000 Roraima Avenue, 97105-900, Brazil

Carlos Eduardo Schaedler

Federal Institute of Education, Science, and Technology (IFSUL), Bagé, 96418-400, Brazil

\section{Felipe Schmidt Dalla Porta \\ Federal University of Pampa (UNIPAMPA), Itaqui, 97650-000, Brazil}

Geovana Facco Barbieri

Department of Plant Protection, Federal University of Santa Maria (UFSM), Santa Maria, 1000 Roraima Avenue, 97105-900, Brazil

\section{André da Rosa Ulguim \\ Department of Plant Protection, Federal University of Santa Maria (UFSM), Santa Maria, 1000 Roraima Avenue, 97105-900, Brazil}

\section{Te Ming Tseng \\ Department of Plant and Soil Sciences, Mississippi State University, Mississippi State, 117 Dorman Hall, MS 39762}

Additional index words. integrated weed management, Manihot esculenta, weed control, weed dynamics, weed species diversity

\begin{abstract}
This study aimed to assess the phytosociology of weeds as a function of different crop management technology levels in cassava production. Field experiments were conducted in Santa Maria $\left(29^{\circ} 41^{\prime} 03^{\prime \prime} \mathrm{S} ; 5^{\circ} 48^{\prime} 2^{\prime \prime} \mathrm{W}\right.$ ) and Itaqui (lat. $29^{\circ} 07^{\prime} 31^{\prime \prime}$ S; long. $5^{\circ} 3^{\prime} 11^{\prime \prime}$ W), Rio Grande do Sul, Brazil. Treatments consisted of three technology levels: low (postemergence weeding without basal dressing); medium (weeding performed at 7 and 40 days after planting and fertilization with $6.25,25$, and 25 $\mathrm{kg} \cdot \mathrm{ha}^{-1}$ of $\mathrm{N}, \mathrm{P}$, and $\mathrm{K}$, respectively); and high (postemergence application of s-metolachlor; $1250 \mathrm{~kg} \cdot \mathrm{ha}^{-1}$ of lime and $12.5,50$, and $50 \mathrm{~kg} \cdot \mathrm{ha}^{-1}$ of $\mathrm{N}, \mathrm{P}$, and $\mathrm{K}$, respectively). Weed frequency, density, relative abundance, and importance values were calculated for each location. Then, locations were compared using a dissimilarity matrix. Weed density and diversity decreased linearly as technology levels increased. The predominant weed species found in Itaqui and Santa Maria belong to the Poaceae family. Itaqui presented highest weed diversity among the locations. The genus Cyperus had the highest importance value index in Santa Maria. The use of S-metolachlor at the high technology level provided a lower frequency and lower diversity of weed species than did levels without chemical control in Itaqui and Santa Maria.
\end{abstract}

Cassava (Manihot esculenta) is an essential crop for food security and provides a significant portion of the diet for up to 800 million people worldwide (El-Sharkawy, 2012). This crop is an essential source for industrial applications for the production of biofuel, ethanol, flour, and biopolymers ( $\mathrm{Li}$ et al., 2017). Despite its high productivity potential, the average yield in Brazil (14.7 $\mathrm{t} \cdot \mathrm{ha}^{-1}$ ) has remained unchanged over the past 5 years, leaving room for considerable improvement (Brazilian Institute of Geography and Statistics, 2018).

The gap between the actual and potential cassava yields is related to management practices in the field (Fermont et al., 2009). In
Brazil, most cassava production is concentrated on small and medium farms, where it is grown as a subsistence crop. In these areas, fewer equipment approaches are used during the growing season, especially regarding weed management. The slow initial growth of cassava delays soil coverage and invasive species suppression, making it susceptible to weed interference, particularly during the first 10 to 16 weeks after planting. Phytosociological surveys performed in cassava cultivation areas indicate that the weed community composition varies among seasons. Malvaceae, Fabaceae, and Poaceae were among the families with the highest number of species in the summer, whereas Convolvulaceae, Malvaceae, and Solanaceae were predominant in the winter (Prates et al., 2019). The storage root yield reduction caused by interference from uncontrolled weeds in cassava fields can reduce $40 \%$ of the total yield (Alabi et al., 2004). Moreover, the long growth cycle of cassava, wide spacing, and slow initial growth favor high weed infestation (Amanullah et al., 2007; Weerarathne et al., 2017).

Preemergence and postemergence herbicides are efficient means of chemically controlling weed populations that require less humanpower than mechanical weed management. However, few are herbicides registered for cassava, and the primary modality used for the chemical control of weeds has been preemergent herbicide applications (Santiago et al., 2018). Essentially, only ametryn, clethodim, clomazone, isoxaflutole, and metribuzin are registered herbicides for cassava in Brazil [Ministry of Agriculture, Livestock and Supply (AGROFIT), 2019]. Still, other herbicides such as flumioxazin, sulfentrazone, and S-metolachlor have been shown to be selective for cassava and can be included in weed management programs (Biffe et al., 2010; Marcos, 2009; Silveira et al., 2012). Hand-weeding is the primary method of weed management for cassava in many Brazilian regions, especially at smallholder farms. The cost of conventional weed management represents $\approx 25.7 \%$ of the total production cost of cassava (Silva and Chabaribey, 2006). Therefore, it is crucial to understand the diversity and dynamics of weed species to establish more efficient control methods (Albuquerque et al., 2012).

Weed communities are affected by various factors, including climate, soil type, soil weed seed bank, planting and production systems adopted, and crop development (Albuquerque et al., 2012). Changes in the soil management system generally influence weed density and diversity (Soares et al., 2016). Phytosociological surveys are useful tools for understanding the dynamics of weed species and their interaction with management systems and agricultural practices (Carvalho and Pitelli, 2012; Concenço et al., 2013). Phytosociology is an ecological evaluation method that characterizes the composition and distribution of plant species present in a plant community, thus assuming an important role in weed science (Concenço et al., 2013). Phytosociology can be used to determine the distribution of weed species 
and their frequency, density, and relative abundance in a specific area (Gama, 2009). The phytosociological survey of rice indicated high weed densities of 10.7, 10.5, and 18.3 plants $/ \mathrm{m}^{2}$ of Echinochloa crus-galli, Echinochloa colona, and Digitaria horizontalis, respectively, in Southern Brazil (Nunes et al., 2017). For forage sorghum under different tillage systems, Cenchrus echinatus had an importance value index of $72.1 \%$ when using the tandem disc harrow, moldboard plow, or chisel plow (Nagahama et al., 2014). Digitaria sanguinalis had the highest relative density $(28.1 \%)$, relative abundance $(26.2 \%)$, and importance value index $(65.3 \%)$ at cassava savanna plantations (Albuquerque et al., 2014). During this study, we hypothesized that the low-input technology for weed control allows a high diversity of weeds to emerge during the growing season, resulting in yield loss of cassava production. Therefore, this research aimed to assess the phytosociology of weeds as a function of different crop management technologies for cassava and its effect on the total yield.

\section{Materials and Methods}

Two field experiments were conducted in 2017 and 2018 at the Federal University of Santa Maria (UFSM), Santa Maria (lat. $29^{\circ} 41^{\prime} 03^{\prime \prime} \mathrm{S}$; long. $53^{\circ} 48^{\prime} 25^{\prime \prime} \mathrm{W}$ ), and Federal University of Pampa (UNIPAMPA), Itaqui (lat. $29^{\circ} 07^{\prime} 31^{\prime \prime} \mathrm{S}$; long. $56^{\circ} 33^{\prime} 11^{\prime \prime} \mathrm{W}$ ), in Southern Brazil. The average rainfall values during the growing season (October-June) were $130 \mathrm{~mm}$ and $150 \mathrm{~mm}$ in Santa Maria and Itaqui, respectively. The temperature in Santa Maria ranged from 12 to $25^{\circ} \mathrm{C}$; in Itaqui, it ranged from 13 to $26^{\circ} \mathrm{C}$. (Fig. 1). Experimental units were plots $23.2 \mathrm{~m}$ long and $9.6 \mathrm{~m}$ wide according to the methodology proposed by Tironi et al. (2015). A strip-plot design with four replications was used. The treatments had three cassava management technology levels (low, medium, and high) and a control that was an unmanaged cassava plot with natural weed infestation. The technology levels represent the crop management practices adopted by the farmers based on the technological approaches used in the production system, including pesticide applications and soil fertilization. The low

Received for publication 14 Dec. 2021. Accepted for publication 30 Mar. 2021.

Published online 8 June 2021.

We thank Bruna Wojahn, Charles Oliveira de Freitas, and Alexandre Ferigolo Alves.

Funding for this project was provided by the Federal University of Santa Maria and the Federal University of Pampa. This material is also based on work that is supported by the National Institute of Food and Agriculture, U.S. Department of Agriculture, Hatch project, under accession number 230100.

T.M.T. is the corresponding author. E-mail: t.tseng@msstate.edu.

This is an open access article distributed under the CC BY-NC-ND license (https://creativecommons. org/licenses/by-nc-nd/4.0/). technology level included hand-weeding at $7 \mathrm{~d}$ after planting (DAP) but did not receive the postemergence herbicide application and no soil $\mathrm{pH}$ correction or fertilization. The medium technology level involved hand-weeding at 7 and 40 DAP; plots were fertilized with 6.3, 25, and $25 \mathrm{~kg} \cdot \mathrm{ha}^{-1}$ of $\mathrm{N}, \mathrm{P}$, and $\mathrm{K}$, respectively. The high technology level consisted of the preemergence application of s-metolachlor (1440 $\mathrm{g}$ a.i./ha) and hand-weeding at 7 and 40 DAP, $1,3 \mathrm{~kg} \cdot \mathrm{ha}^{-1}$ of lime $\left(\mathrm{CaCO}_{3}, \mathrm{TNP} 75 \%\right)$, and $12.5,50$, and $50 \mathrm{~kg} \cdot \mathrm{ha}^{-1}$ of $\mathrm{N}, \mathrm{P}$, and $\mathrm{K}$, respectively. Herbicide was sprayed using a backpack sprayer with flat fan nozzles (model XR 110.015; TeeJet, Glendale Heights, IL) and calibrated to deliver $150 \mathrm{~L} \cdot \mathrm{ha}^{-1}$.

A

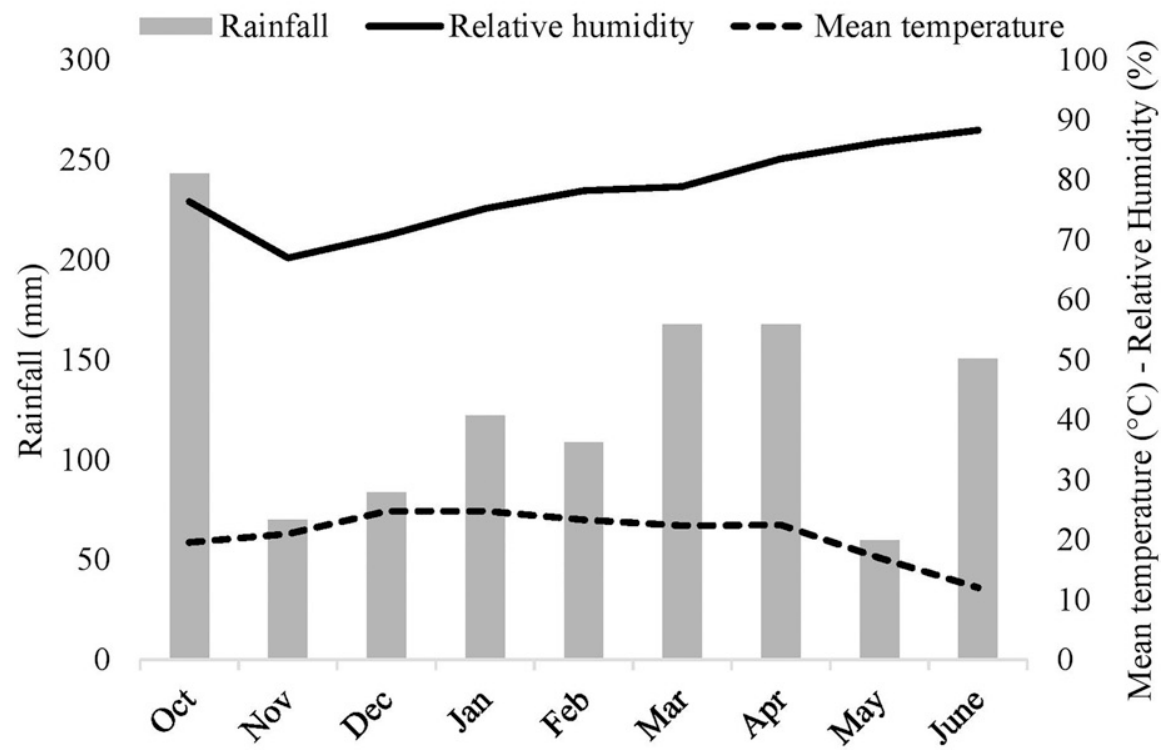

B Itaqui

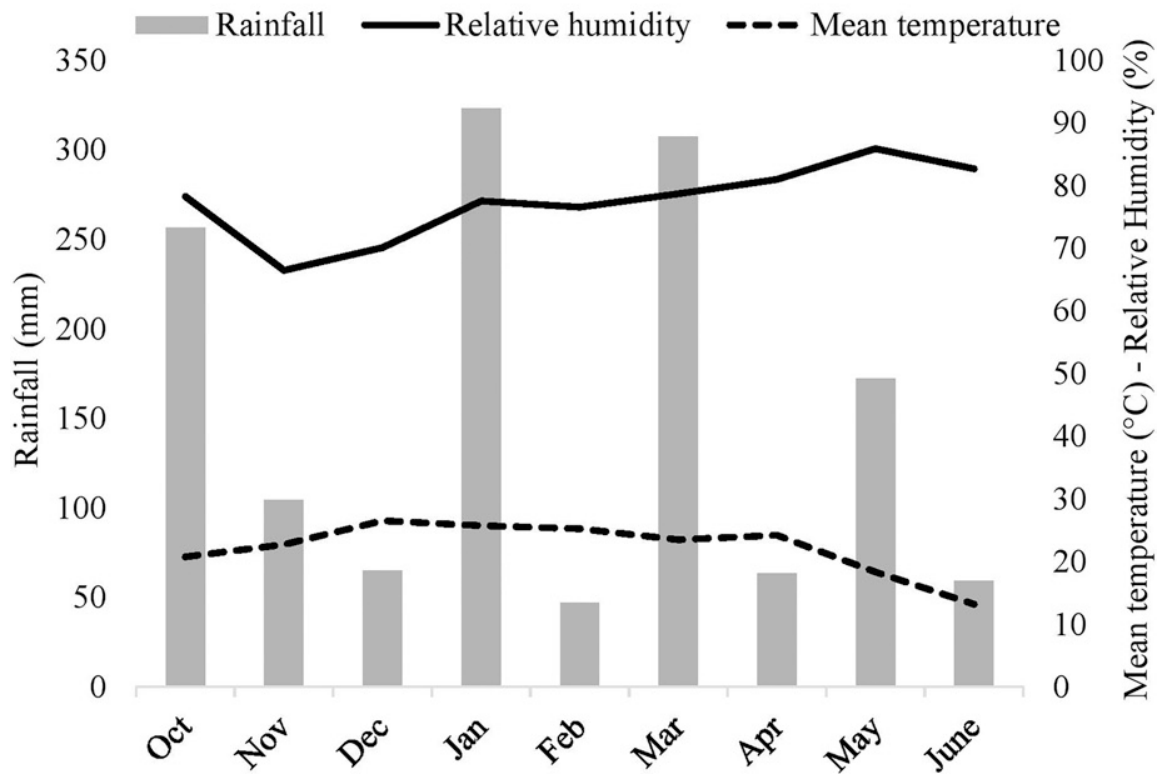

Fig. 1. Climatic data related to rainfall, mean temperature, and relative humidity during the period from Oct. 2017 to June 2018, in Santa Maria (A) and Itaqui (B).
The base dressing was supplemented with single superphosphate, potassium chloride $(\mathrm{KCl}$ ), and nitrogen (urea) 45 DAP. The fertilization and liming levels represent half the recommended dose and the full recommended dose for medium and high technology levels, respectively, based on soil analysis (Table 1) and in line with liming and fertilization recommendations (SBCS, 2004). The field was prepared using a conventional approach, and the cultivar Vassourinha was planted on ridges on 4 and 27 Oct. 2017, for the experiments in Santa Maria and Itaqui, respectively. Vassourinha is one of the commercial standard cultivars in the Southern regions of Brazil. This cultivar has a high number of lateral branches and 
Table 1. Soil analysis results for $\mathrm{pH}$ in water $\left(\mathrm{H}_{2} \mathrm{O}\right)$, organic matter $(\mathrm{OM})$, phosphorus $(\mathrm{P})$, and potassium $(\mathrm{K})$ content areas for the different technology levels before the initiation of the experiment in Itaqui and Santa Maria.

\begin{tabular}{llllccr}
\hline Location & $\begin{array}{c}\text { Texture } \\
\text { classification }\end{array}$ & $\mathrm{pH}$ & $\begin{array}{c}\text { Technology } \\
\text { level }\end{array}$ & $\begin{array}{c}\text { OM content } \\
(\%)\end{array}$ & $\begin{array}{c}\mathrm{P} \text { content } \\
\left(\mathrm{kg} \cdot \mathrm{ha}^{-1}\right)\end{array}$ & $\begin{array}{r}\mathrm{K} \text { content } \\
\left(\mathrm{kg} \cdot \mathrm{ha}^{-1}\right)\end{array}$ \\
\hline Itaqui & Clay loam & 6.0 & Low & 0.2 & 14.76 & 112 \\
& & 5.1 & Medium & 0.2 & 14.76 & 112 \\
\multirow{2}{*}{ Santa Maria } & & 5.3 & High & 1.1 & 12.6 & 78 \\
& Sandy loam & 6.0 & Low & 2 & 43.2 & 280 \\
& & 6.0 & Medium & 2 & 43.2 & 280 \\
& & 6.0 & High & 2 & 43.2 & 280 \\
\hline
\end{tabular}

sprouting, and it can reach up to $1.5 \mathrm{~m}$ high. Some of the marketable qualities of cultivar Vassourinha are its white pulp, ease of peeling, and fast cooking (Tironi et al., 2019).

The experimental areas were infested with weed species, and no weed sowing was performed before planting cassava. Four phytosociological surveys were performed at 7 , 40, 80, and 96 DAP. The survey sampling was collected from a $1-\mathrm{m}^{2}$ area, and the number of weed seedlings was counted and identified at the genus level. In addition to the botanical classification based on quantitative species data, the phytosociological parameters relative frequency ( $R F r$ ), relative density (RDe), relative abundance (RAb), and importance value index (IVI) were assessed according to Mueller-Dombois and Ellenberg (1974), in line with the following equations:

Frequency $(\mathrm{F})=$ number of samplings in which the species were found total number of samplings

a. Relative frequency $(\mathrm{RFr})=\mathrm{F} \times$ $100 /$ total species frequency

b. Density $(\mathrm{De})=$ number of plants found for the species $/ 0.25 \mathrm{~m}^{2}$

c. Relative density $(\mathrm{RDe})=\mathrm{De} \times 100 /$ total species density

$$
\begin{aligned}
& =\mathrm{RAb} \\
& =\mathrm{RDe} \\
& =\mathrm{RFr}
\end{aligned}
$$

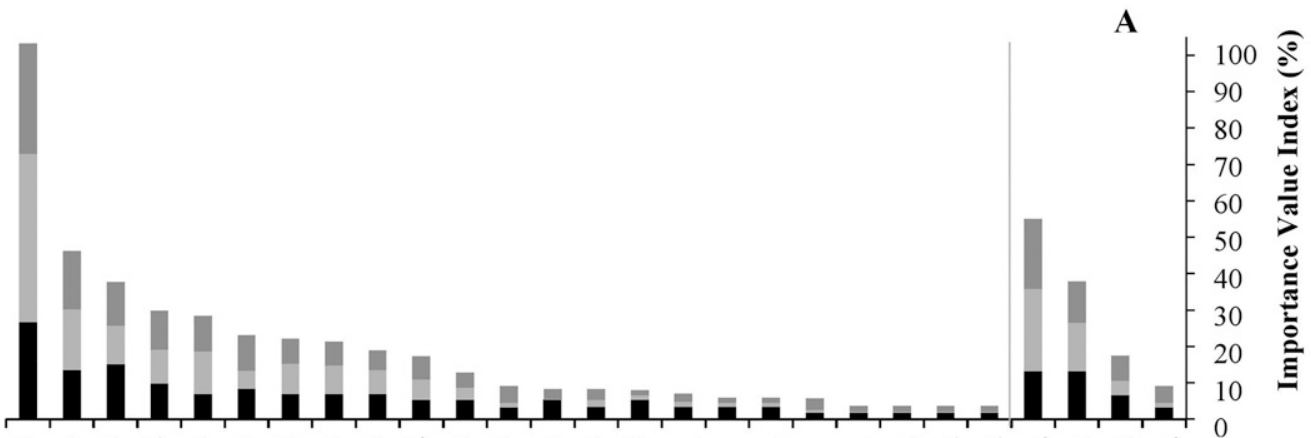

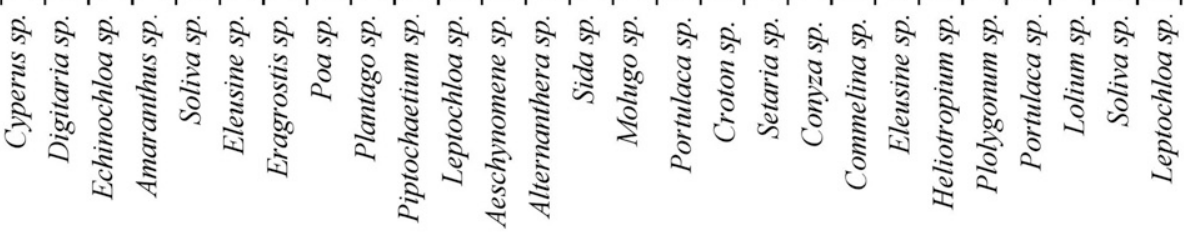

Low and Medium Levels

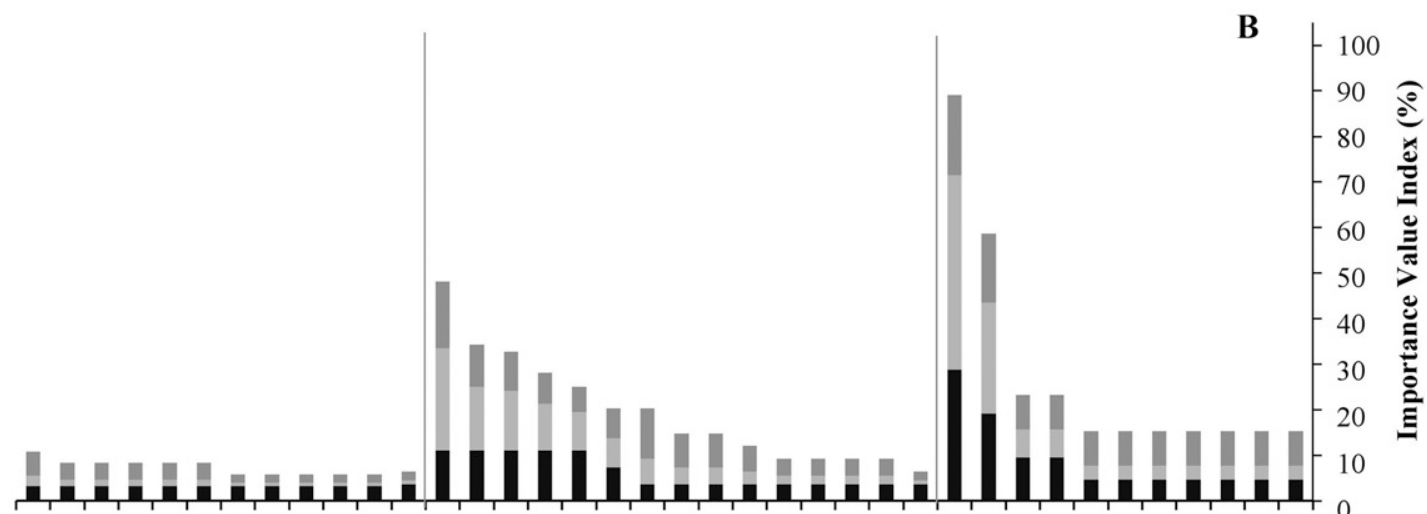

Low Level

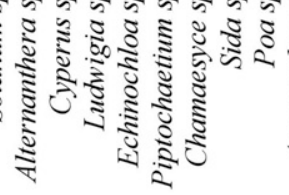

Medium Leve
High Level

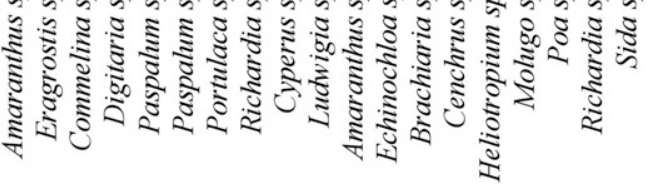

High Level

Fig. 2. Relative frequency (RFr), relative density (RDe), and relative abundance (RAb) percentages of different weed species as a function of low, medium, and high technology levels for cassava crops in Itaqui/Rio Grande do Sul during surveys performed before the first weeding (A) and second weeding (B). 


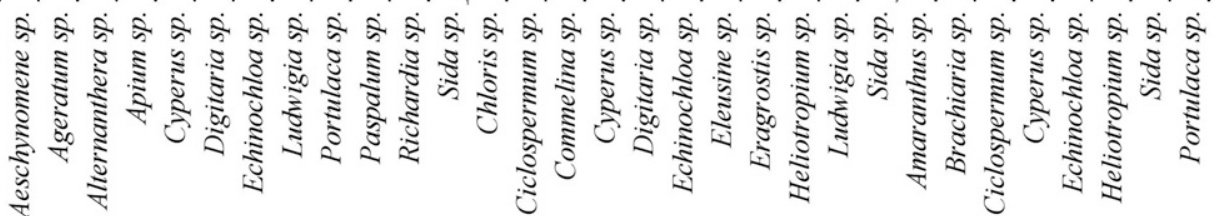

Low Level

Medium Level

High Level

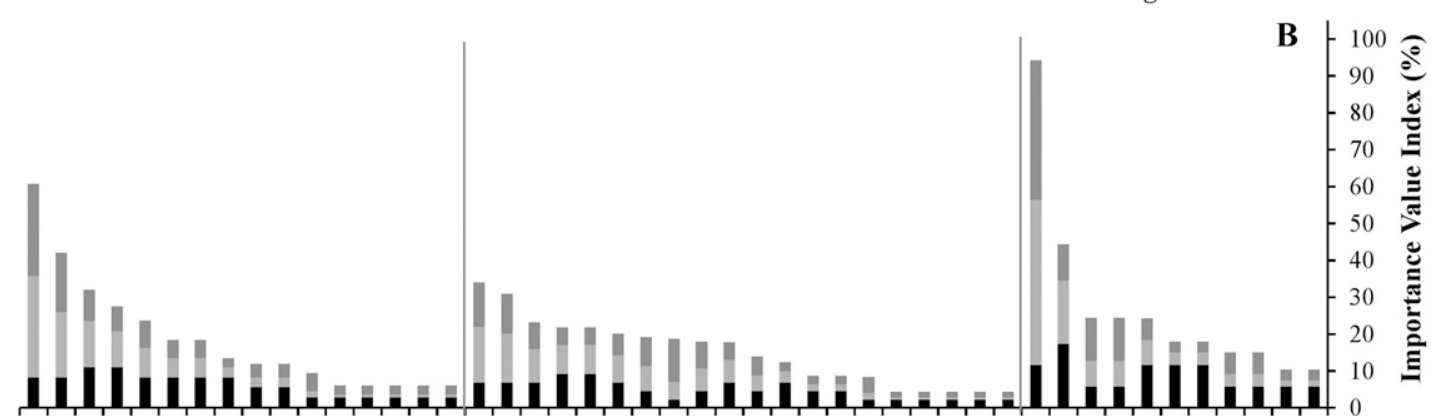

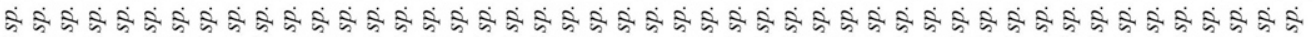

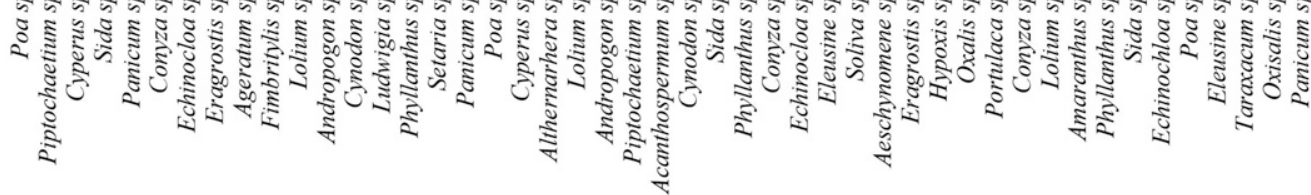

Low Level

Medium Level

High Level

Fig. 3. Relative frequency ( $R F r$ ), relative density (RDe), and relative abundance (RAb) percentages of different weed species as a function of low, medium, and high technology levels for cassava crops in Itaqui/Rio Grande do Sul during surveys performed before the third weeding (A) and fourth weeding $(\mathbf{B})$.

d. Abundance $(\mathrm{Ab})=$ number of plants found for the species/total number of samplings in which the species was found

e. Relative abundance $(\mathrm{RAb})=\mathrm{Ab} \times$ 100/total species abundance

f. Importance value index (IVI) $=\mathrm{RFr}$ $+\mathrm{RDe}+\mathrm{RAb}$

In these equations, RDe, RFr, and RAb represent the number of species, their distribution, and concentration with other species in the sampled area, respectively, whereas IVI indicates the most important species in the study area. Total frequency, density, and abundance were obtained from the sum of the relative number of each of the parameters within the technology level. Additionally, the study sites, located in different municipalities and regions, were compared as follows using the similarity matrix in accordance with Sorensen (1972):
Similarity index $(\mathrm{SI})=2 \times$ number of species in both environments/number of species found in environment $1+$ number of species found in environment 2

This equation was used to obtain the dissimilarity matrix ( 1 - similarity) and for constructing a dendrogram using the unweighted pair-group method with arithmetic mean (Sneath and Sokal, 1973). A statistical analysis was performed using Genes 2013.5.1 (Federal University of Viçosa, Minas Gerais, Brazil) for Windows software.

\section{Results and Discussion}

The composition of the weed community in the experimental areas was heterogeneous. A total of 56 different weed genera were identified, nine of which were common to both regions studied. The Poaceae family had the largest number of distinct genera, totaling $32 \%$, followed by Cyperaceae and Asteraceae, with $14 \%$ and $11 \%$, respectively. The highest species diversity was recorded in Itaqui, with 46 different genera identified from a total of 56 observed during the four phytosociological surveys conducted at both locations.

The low incidence of weeds found at the high technology level, especially in the first through fourth surveys in Santa Maria (Figs. 4 and 5), was primarily attributable to the control spectrum and persistence in the soil with the preemergence herbicide S-metolachlor applied in this treatment. The high fertility level also had an essential role because it enabled cassava plants to overgrow and suppress the weeds in these plots. S-metolachlor is used primarily because of its activity inhibiting germination on grasses, with a control period between 25 and $90 \mathrm{~d}$ after crop planting (Albuquerque et al., 2012). Studies of cassava crops have found that flumioxazin $\left(60 \mathrm{~g} \cdot \mathrm{ha}^{-1}\right)$, sulfentrazone $\left(600 \mathrm{~g} \cdot \mathrm{ha}^{-1}\right)$, and S-metolachlor $\left(1.9 \mathrm{~g} \cdot \mathrm{ha}^{-1}\right)$ provide excellent weed control without causing visible symptoms of phytotoxicity in cassava 

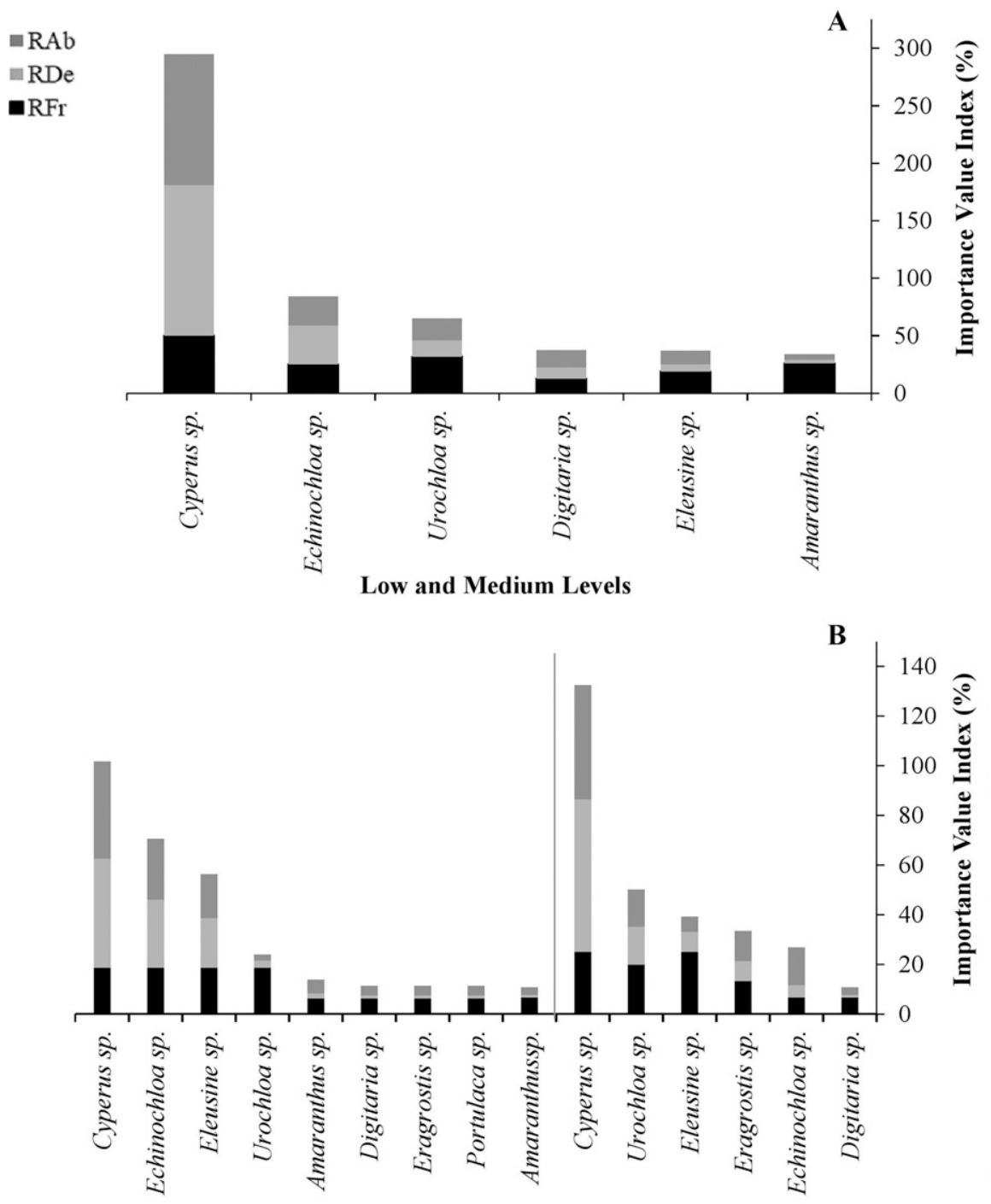

Low Level

Medium Level

Fig. 4. Relative frequency (RFr), relative density (RDe), and relative abundance (RAb) percentages of different weed species as a function of low, medium, and high technology levels for cassava crops in Santa Maria/Rio Grande do Sul during surveys performed before the first weeding (A) and second weeding (B).

plants (Scariot et al., 2013). Chemical control in the form of preemergence herbicides is additionally beneficial for managing weeds in the early stages of crop development, thereby preventing initial competition and favoring cassava growth.

Different species stood out across the surveys as a function of plant characteristics, weather and climate conditions, soil seed bank, cassava growth stage, and the technology level used. In general, the lower the technology level, the higher the diversity and number of weeds (Figs. 2-5); however, the number of different weed species decreased significantly with high-level technology, particularly those belonging to the Poaceae family during the first three phytosociological surveys (Figs. 2-5). A comparison of the three technology levels involving different crop treatments indicated changes in the weed species composition and the degree of infestation at both sites according to the type of management. Weeds belonging to the genus Cyperus exhibited the highest RFr, RDe, and $\mathrm{RAb}$ values and the largest IVI overall during the first phytosociological survey (Figs. 2 and 4).

First weed survey. The low and medium technology levels were combined during the first survey because no difference in their control treatments was observed. During this survey in Itaqui, plants of the Cyperus, Digitaria, and Echinochloa species exhibited the highest IVI values $(125.9 \%, 55.4 \%$, and $51.0 \%$, respectively) (Fig. 2A). The number of species found at the high technology level was lower. Portulaca and Lolium species had IVI values of $55.0,37.8$, and $17.4 \%$, respectively (Fig. 2A). In Santa Maria, the survey conducted before the first weeding identified six weed genera at the low and medium technology levels, namely, Cyperus, Echinochloa, Urochloa, Digitaria, Eleusine, and Amaranthus species (Fig. 4A). Of these,
Cyperus sp. displayed the highest RDe and RAb values, characterizing a high plant population per area, uniform distribution, and 295\% IVI (Fig. 4A). Cyperus weed species are a significant problem in Brazilian cassava crops, particularly during the first 3 months after planting (Viégas, 1976), making them a relevant target for control. This supports our findings that the genus Cyperus exhibited, in general, the highest RFr, RDe, and RAb and, consequently, the largest IVI during the first survey performed at both locations with the low and medium technology levels. In the case of low infestation by species from the family Cyperaceae, cassava can grow alongside these plants with no significant reduction in growth or total dry weight accumulation, and adequate management techniques can mitigate their harmful effects (Jakelaitis et al., 2003).

Second weed survey. The species with the highest IVI with low technology in Itaqui were Piptochaetium sp. (10.8\%) and Cenchrus sp. (8.3\%) (Fig. 2B). Unlike previous surveys, the genus Cyperus was not present because of a higher infestation of plants from the family Poaceae and perennial eudicots. At the high and medium technology levels, Cyperus and Ludwigia species displayed high IVI values (Fig. 2B) differing from values achieved with the previous management practices applied and nutrient availability for the establishment of different weed species. At the low and medium technology levels in Santa Maria, plants from the Cyperus, Echinochloa, Eleusine, and Urochloa families exhibited the highest IVI values (Fig. 4B).

Third weed survey. During the third survey, the species with the highest relative density, abundance, and IVI among the technological levels in Itaqui were Aeschynomene and Ageratum sp. With the medium technology level, Chloris and Ciclospermum sp. were the most predominant, whereas with the high technology level, Amaranthus and Brachiaria sp. had the highest density and IVI (Fig. 3A). Six weed species were found in Santa Maria, with Urochloa, Cyperus, and Echinochloa species exhibiting the largest IVI values (Fig. $5 \mathrm{~A})$ at the low and medium technology levels. The phytosociological survey conducted during this period showed a predominance of Poaceae plants, thus justifying the critical need to control these species in cassava fields. Plants from the genus Echinochloa predominantly occur in aquatic environments, and those found in cassava fields can be considered local or regional problems because each location has its peculiarities regarding the weeds present; however, many are common among cassava-producing regions (Albuquerque et al., 2008). Urochloa species, however, are highly adaptable to several different crops. Urochloa species are widespread in most farms in Southern Brazil because they are used in the pasture for livestock production in these regions. This species presents an annual cycle and seed reproduction, meaning it is easily distributed over time (Lorenzi, 1991).

Fourth weed survey. The highest IVI values during the last weed survey in Itaqui 

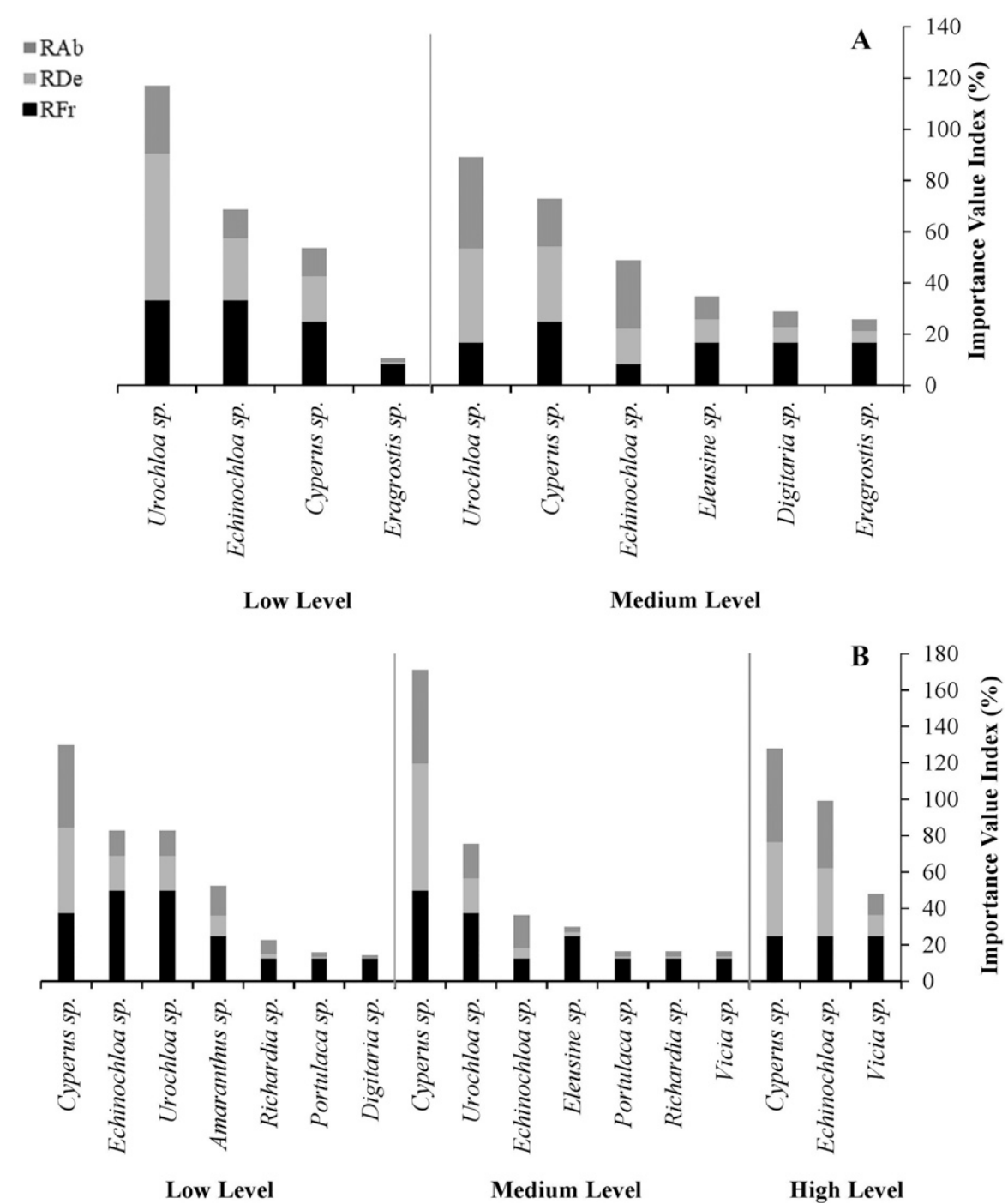

Fig. 5. Relative frequency (RFr), relative density (RDe), and relative abundance (RAb) percentages of different weed species as a function of low, medium, and high technology levels for cassava crops in Santa Maria/Rio Grande do Sul during surveys performed before the third weeding (A) and fourth weeding $(\mathbf{B})$.

were recorded with low technology for Poa and Piptochaetium sp. (60.7 and $42.1 \%$, respectively), thus confirming the predominance of grassy weeds (Fig. 3B). With the medium technology level, IVI values were low for all the species found, most notably Panicum sp. (34.0\%) and Poa sp. (30.8\%), likely because of a large number of different genera (29). In contrast, the most prominent plants with high technology were Conyza sp. Plants from the genus Conyza are not controlled by the preemergence herbicide (S-metolachlor) used with the high technology level, which may have favored their higher occurrence during the fourth survey in Itaqui. The low population of the remaining species can be attributed to interspecific competition with a dominant species (Jakelaitis et al., 2003). The increased incidence of plants from the monocotyledon group during the fourth survey in Santa Maria indicated that the herbicide activity in the soil had ceased by this time, allowing the emergence of species from genus Cyperus and Echinochloa (Fig. 5A). The herbicide s-metolachlor exhibits moderate to long persistence in soil, depending on climate, tillage, and soil drainage (Zemolin et al., 2014). Albuquerque et al. (2012) assessed the occurrence of weeds after maize emergence in the Cerrado region of Roraima, Brazil, and obtained similar results; the species with the most significant number of individuals per hectare were Cyperus and Urochloa.

Weed similarity index in Itaqui and Santa Maria. The dynamics of weed occurrence, their frequency, density, and abundance change according to the location and agricultural production system used. As such, comprehensive information is needed to determine the characteristics of the invasive weed community in an area. In this context, the SI makes it possible to compare the incidence of weed species in different cultivated regions and at different times. The SI is the result of the dendrogram obtained from the dissimilarity matrix constructed via the unweighted pair- group method with arithmetic mean, with the lowest value $(0 \%)$ indicating that all the species are common to the areas compared and the highest value $(100 \%)$ indicating that no species are common. The SI revealed interspecies similarities at the different locations and phytosociological survey times.

In Santa Maria, Cyperus, Echinochloa, and Urochloa species stood out with the low and medium technology levels. Under highlevel technology, only three species were found (Cyperus, Echinochloa, and Vicia), with the Cyperus and Echinochloa species being the most significant, with IVI of 128 and $99 \%$, respectively. The dendrogram indicated the formation of two groups, with a subgroup in each, for surveys 1 and 4 at both locations, thus obtaining an SI of $70 \%$ (Fig. $6 \mathrm{~B}$ ). Moreover, the other two subgroups were formed between survey 3 in Santa Maria and survey 2 in Itaqui, with a $75 \%$ SI. However, despite the formation of subgroups, the comparison between levels and locations showed 100\% dissimilarity (Fig. 6A).

The higher similarity between the first and fourth surveys as well as between the second and third surveys can be explained by the effect of the environment, whereby the early planting of cassava setts in Santa Maria may have provided favorable microenvironment conditions for the emergence of certain weeds when compared with Itaqui. The variations in soil type, $\mathrm{pH}$, organic matter, $\mathrm{P}$ contents, and $\mathrm{K}$ contents across locations are factors that impact the diversity and emergence pattern of weed species found in the study. However, the lack of interspecies similarity for the different levels and locations corroborates the phytosociological indices regarding changes in the floristic composition. Similarity indices not only are associated with soil type or study locations but also may be related to the management practices used (Carvalho and Pitelli, 2012). These changes can alter the germination and development of certain weeds.

During the present study, the most significant differences with respect to the phytosociological parameters of the weeds were found with the low and medium technology levels. The genus Cyperus exhibited the highest IVI in Itaqui and Santa Maria across all phytosociological surveys. The family Poaceae was the most abundant among the weed species identified, and its importance value decreased with the use of S-metolachlor with the high technology level. The lower incidence of weeds with the high technology level can be explained by the association of practices in crop management, such as the use of a preemergence herbicide application, correction of soil $\mathrm{pH}$, and soil fertilization. Information regarding the biology and ecology of weeds is essential for implementing integrated weed management programs for these species. Current phytosociological surveys have shown that the degree of infestation in crops is influenced by weed characteristics such as density, frequency, and abundance, which vary according to the study location. In this case, effective weed control requires 
A

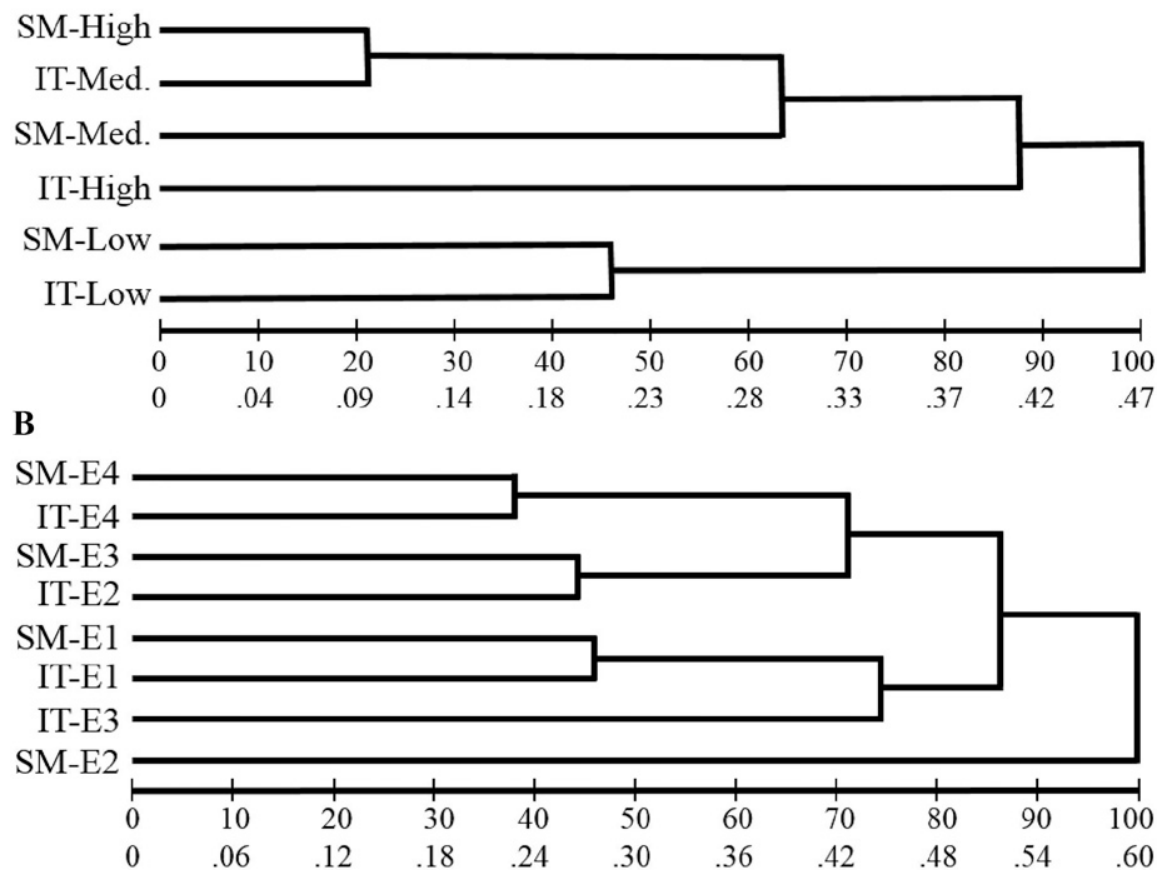

Fig. 6. Dendrograms of floristic similarity among technology levels and collection sites (A) and among collection sites and times $(\mathbf{B})$ obtained from the dissimilarity matrix constructed via the unweighted pair-group method with arithmetic mean (UPGMA) based on the phytosociological surveys conducted in Itaqui and Santa Maria. SM-High, Med, and Low correspond to high, medium, and low technology levels in Santa Maria/Rio Grande do Sul, respectively. IT-High, Med, and Low correspond to high, medium, and low technology levels in Itaqui/Rio Grande do Sul, respectively. SM_E1, E2, E3, and E4 correspond to the first, second, third, and fourth collection times in Santa Maria, respectively. IT_E1, E2, E3, and E4 correspond to the first, second, third, and fourth collection times in Itaqui/Rio Grande do Sul, respectively.

integrated strategies to adopt sustainable management practices, thereby lowering production costs and yield losses.

\section{Literature Cited}

Alabi, B.S., A.O. Albert, A.A. Akinola, and M.A Bradley. 2004. Manual control of thorny mimosa (Mimosa invisa) in cassava (Manihot esculenta). Weed Technol. 18:77-82, doi: 10.1614/0890037X(2004)018[0077:MCOTMM]2.0.CO;2.

Albuquerque, J.A.A., M.O. Evangelista, A.P.K. Mates, J.M.A. Alves, N.T. Oliveira, T. Sediyama and A.A. Silva. 2014. Occurrence of weeds in Cassava savanna plantations in Roraima. Planta Daninha 32:91-98, doi: 10.1590/S010083582014000100010.

Albuquerque, J.A.A., T. Sediyama, A.A. Silva, J.E.S. Carneiro, P.R. Cecon, and J.M.A. Alves. 2008. Weed interference in cassava (Manihot esculenta) yield. Planta Daninha 26:279-289, doi: 10.1590/S0100-83582008000200004.

Albuquerque, J.A.A., V.F. Melo, R.H.S. Siqueira, S.A. Martins, E.L. Finoto, T. Sediyama, and A.A. Silva. 2012. Occurrence of weeds after corn cultivation in the Amazonian savannah. Planta Daninha 30:775-782, doi: 10.1590/ S0100-83582012000400011.

Amanullah, M.M., E. Somasundaram, K. Vaiyapuri, and K. Sathyamoorthi. 2007. Intercropping in cassava-a review. Agr. Rev. 28:179-187, doi: 10.1016/0378-4290(93)90125-7.

Biffe, D., J. Constantin, R.S. Oliveira, F. Rios, L.H.M. Franchini, A. Gemelli, J.G.Z. Arantes,
M.A. Raimondi, and E. Blainski. 2010. Selectivity of herbicide alternatives for two cassava cultivars. Planta Daninha 28:807-816, doi: $10.1590 / \mathrm{S} 0100-83582010000400014$.

Brazilian Institute of Geography and Statistics. 2018. Systematic Survey of Agricultural Production LSPA. Rio Grande do Sul, 2018. 2 Nov. 2018. $<$ https://sidra.ibge.gov.br/pesquisa/lspa/tabelas $>$.

Brazilian Society of Soil (SBCS). 2004. Manual fertilization and liming for the states of Rio Grande do Sul and Santa Catarina. Comission of Chemistry and Fertility of Soils, Rio Grande do Sul.

Carvalho, S. and R.A. Pitelli. 2012. Survey and phytosociological analysis of the main pasture weed species of Selvíria region (MS). Planta Daninha 10:25-32, doi: 10.1590/S0100-835819 92000100001

Concenço, G. M., M. Tomazi, I.V.T. Correia, S.A. Santos, and L. Galon. 2013. Phytosociological surveys: Tools for weed science? Planta Daninha 31:469-482, doi: 10.1590/S0100-835820130002 00025 .

El-Sharkawy, M.A. 2012. Stress-tolerant Cassava: Stress-breeding research in crop improvement. J. Soil Sci. 2:162-186, doi: 10.4236/ ojss.2012.22022.

Fermont, A.M., P.J. Asten, P. Tittonell, M.T. Wijk, and K.E. Giller. 2009. Closing the cassava yield gap: An analysis from smallholder farms in East Africa. Field Crops Res. 112:24-36, doi: 10.1016/j.fcr.2009.01.009.

Gama, J.C. 2009. Floristics and phytosociology of spontaneous plants in anthropized communities of cerrado in Minas Gerais. 10 Nov. 2018. <http:// www.bibliotecadigital.ufmg.br/dspace/bitstream/ handle/1843/NCAP-8A8GNQ/disserta_o_jord_ nia_mac_do.pdf?sequence $=1>$.

Jakelaitis, A., L.R. Ferreira, A.A. Silva, E.L. Agnes, G.V. Miranda, and A.F.L. Machado. 2003. Weed population dynamics under different corn and bean production systems. Planta Daninha 21:71-79, doi: 10.1590/S0100-835820030 00100009.

Li, S., Y. Cui, Y. Zhou, Z. Luo, J. Liu, and M. Zhao. 2017. The industrial applications of cassava: Current status, opportunities and prospects. J. Sci. Food Agr. 97:2282-2290, doi: $10.1002 /$ jsfa. 8287.

Lorenzi, H. 1991. Weeds of Brazil: Terrestrial, aquatic, parasitic and toxic. 4th ed. New Odessa: Plantarum

Marcos, F. 2009. Selective herbicides molecules to cassava cultivation. Weeds. 61-72.

Ministry of Agriculture, Livestock and Supply (AGROFIT). 2019. Phytosanitary pesticide system. 28 Oct. 2019. <http://agrofit.agricultura. gov.br/agrofit_cons/principal_agrofit_cons $>$.

Mueller-Dombois, D. and H.A. Ellenberg. 1974 Aims and methods of vegetation ecology. John Wiley and Sons, New York.

Nagahama, H.J., J.W. Cortez, G. Concenço, V.F. Araújo, and A. Honorato. 2014. Dynamics and spatial variability of weeds under soil tillage systems in forage sorghum. Planta Daninha 32:265-274, doi: 10.1590/S0100-83582014000200003.

Nunes, F.S., C.E. Schaedler, and D.M. Chiapinotto. 2017. Weed phytosociological survey in irrigated rice. Planta Daninha 35:e017166625, doi: 10.1590/s0100-83582018360100044.

Prates, C.J.N., A.E.S. Viana, A.D. Cardoso, A.R Sao Jose, B.A.R. Viana, and F. Dutra. 2019 Weed phytosociology in cassava cultivation in two periods in southwestern Bahia, Brazil. Planta Daninha 37:e019208668, doi: 10.1590/ s0100-83582019370100107.

Santiago, A.D., M.H.B. Cavalcante, G.B.P. Braz and S.O. Procópio. 2018. Efficacy and selectivity of herbicides applied in cassava preemergence. Revista Caatinga 31:640-650.

Scariot, C.A., N. Costa, E.P. Bosquese, D.C. Andrade and D.A. Sontag 2013. Selectivity and efficiency of pre-emergence herbicides on cassava crop. Pesq. Agrop. Trop. 4:300-307, doi: 10.1590/S1983-40632013000300012.

Silva, J.R. and D. Chabaribery. 2006. Technical coefficients and cost of production of cassava for table in the region of Mogi-Mirim. Econ. Inf. 36:26-32.

Silveira, H.M., E.A. Ferreira, D.V. Silva, M.D.C. Neto, F.P. Carvalho, J.B. Santos, and A.A. Silva. 2012. Physiological characteristics of cassava cultivars after mesotrione application. Planta Daninha 31:403-409, doi: 10.1590/S010083582013000200018

Sneath, P.H., and R.R. Sokal. 1973. Numerical taxonomy: The principles and practices of numerical classification. WH Freeman, São Francisco.

Soares, M.B.B., S. Bianco, E.L. Finoto, D. Bolonhezi, J.A.A. Albuquerque and A.A. Silva. 2016. Weed community in a raw sugarcane renovation area submitted to different soil managements. Planta Daninha 34:91-98, doi: 10.1590/S0100-83582016340100009.

Sorensen, T.A. 1972. A method of establishing groups of equal amplitude in plant society based on similarity of species content, p. 341-405. In: E.P. Odum (ed.). Ecologia.

Tironi, L.F. A.F. Alves, A.F. A.J. Zanon, C.O.P. Freitas, A.T.L. Santos, P.S. Cardoso, G.P. Tonel, G.P., L.B. Rodrigues, B.L. 
Tagliapietra, M.N. Silva and N.A. Streck. 2019. Ecophysiology of cassava for high productivity. Palloti graphics, Santa Maria, Rio Grande do Sul.

Tironi, L.F., L.O. Uhlmann, N.A. Streck, F.K. Samboranha, C.P.O. Freitas, and M.R. Silva.

2015. Performance of cassava cultivars in subtropical environment. Bragantia 74:58-66, doi: 10.1590/1678-4499.0352.

Viégas, A.P. 1976. Studies about cassava. IAC/ Brascan Nordeste, Brazil.

Zemolin, C.R., L.A. Avila, G.V. Cassol, J.H. Massey, and E.R. Camargo. 2014. Environmental fate of S-Metolachlor - A review. Planta Daninha
32:655-664, doi: 10.1590/S0100-83582014 000300022.

Weerarathne, L.V.Y., B. Marambe, and B.S. Chauhan. 2017. Does intercropping play a role in alleviating weeds in cassava as a non-chemical tool of weed management? - A review. Crop Prot. 95:81-88, doi: 10.1016/j.cropro.2016.08.028. 